\title{
Higher glandular trichome density in tomato leaflets and repellence to spider mites
}

\author{
Wilson Roberto Maluf(1), Irene Fumi Inoue ${ }^{(1)}$, Raphael de Paula Duarte Ferreira(1), Luiz Antonio Augusto Gomes ${ }^{(1)}$, \\ Evaristo Mauro de Castro ${ }^{(2)}$ and Maria das Graças Cardoso ${ }^{(3)}$
}

\begin{abstract}
(1)Universidade Federal de Lavras (Ufla), Dep. de Agricultura, Caixa Postal 3037, CEP 37200-000 Lavras, MG, Brazil. E-mail: wrmaluf@ufla.br, fuminoue@yahoo.com.br, raphaelufla@yahoo.com.br, laagomes@ufla.br (2)Ufla, Dep. de Biologia. E-mail: emcastro@ufla.br (3)Ufla, Dep.de Química. E-mail: mcardoso@ufla.br
\end{abstract}

\begin{abstract}
The objective of this work was to evaluate the feasibility of selection for higher glandular trichome densities, as an indirect criterion of selection for increasing repellence to spider mites Tetranychus urticae, in tomato populations derived from an interspecific cross between Lycopersicon esculentum $\mathrm{x}$ L. hirsutum var. glabratum PI 134417. Trichome densities were evaluated in 19 genotypes, including 12 from advanced backcross populations, derived from the original cross L. esculentum x L. hirsutum var. glabratum PI 134417. Counts were made both on the adaxial and abaxial leaf surfaces, and trichomes were classified into glandular types IV and VI, other glandular types (types I+VII), and nonglandular types. Mite repellence was measured by distances walked by mites onto the tomato leaf surface after 20,40 and $60 \mathrm{~min}$. Spider mite repellence biotests indicated that higher densities of glandular trichomes (especially type VI) decreased the distances walked by the mites onto the tomato leaf surface. Selection of plants with higher densities of glandular trichomes can be an efficient criterion to obtain tomato genotypes with higher resistance (repellence) to spider mites.
\end{abstract}

Index terms: Lycopersicon hirsutum, Tetranychus urticae, 2-tridecanone, methyl-ketone, resistance.

\section{Alta densidade de tricomas glandulares em tomateiro e aumento da repelência a ácaros rajados}

\begin{abstract}
Resumo - O objetivo deste trabalho foi avaliar a eficiência da seleção para maior densidade de tricomas glandulares na resistência (repelência) ao ácaro Tetranychus urticae, em populações de tomate derivadas do cruzamento interespecífico Lycopersicon esculentum x L. hirsutum var. glabratum PI 134417. Foram avaliados 19 genótipos quanto à densidade de tricomas, que incluíram 12 derivados de populações avançadas de retrocruzamentos, obtidos a partir do cruzamento original L. esculentum x L. hirsutum var. glabratum PI 134417. Nas faces abaxial e adaxial dos folíolos, realizaram-se as contagens e os tricomas foram classificados em glandulares tipo IV e VI, outros glandulares (tipo I e VII) e não glandulares. A repelência aos ácaros foi medida pela distância média, percorrida pelo ácaro na superfície do folíolo de tomateiro, após 20, 40 e $60 \mathrm{~min}$. Os biotestes de repelência ao ácaro rajado demonstraram que a alta densidade de tricomas glandulares, especialmente de tipo VI, influencia negativamente a distância média percorrida pelos ácaros na superfície do folíolo. Plantas com número de tricomas glandulares elevado podem ser selecionadas para se obterem genótipos com alto índice de repelência aos ácaros.
\end{abstract}

Termos para indexação: Lycopersicon hirsutum, Tetranychus urticae, glabratum, 2-tridecanona, metil-cetona, resistência.

\section{Introduction}

Current levels of cultivar resistance are not high enough to permit a significant decrease in the amounts of pesticides applied on tomato crop. Breeding cultivars comprising higher levels of pest resistance can, therefore, become an important component in an integrated pest management programme.
Even though not considered key tomato pests in Brazil, spider mites Tetranychus spp. can become very destructive pests, when they find appropriate conditions for their development, such as high temperature and low relative humidity. These mites may feed on both sides of the leaflets, and their action may inhibit photosynthesis and promote leaf fall. A number of wild accessions of Lycopersicon have been reported to be resistant to a 
wide array of tomato pests, including spider mites (Gentile et al., 1969), but these plant species do not have immediate commercial value. Breeding programmes aimed at introgressing their arthropod resistance into cultivated tomato face difficulties in keeping uniform conditions of infestation necessary to select for resistance, and genetic progress has therefore been slow.

Indirect selection techniques, based on correlated traits with high heritability, could be used to speed up that introgression. Several allelochemicals present in wild Lycopersicon taxa have been associated with pest resistance: methyl-ketones such as 2-tridecanone (2-TD) in L. hirsutum var. glabratum (Maluf et al., 1997; Gonçalves et al., 1998); sesquiterpenes in $L$. hirsutum var. hirsutum (Snyder et al., 1987; Eigenbrode et al., 1994; Azevedo et al., 2003, Gonçalves et al., 2006); acylsugars in L. pennellii (Resende et al., 2002; Gonçalves, 2006). Selection for high allelochemical content would therefore be an efficient indirect selection technique. Indeed, there is strong evidence that selection for high 2-TD, sesquiterpene or acylsugar contents will increase the levels of resistance to the South American tomato pinworm (Maluf et al., 1997; Azevedo et al., 2003; Resende et al., 2006), to the silverleaf whitefly (Freitas et al., 2002; Resende, 2003) and to spider mites (Gonçalves et al., 1998; Maluf et al., 2001; Resende, 2003; Gonçalves, 2006). Spider mite Tetranychus spp. repellence can be measured by quick, inexpensive techniques (Weston \& Snyder, 1990), and can therefore be taken as indicative of the resistance level to other arthropod pests (Aragão et al., 2000a; Maluf et al., 2001).

High levels of allelochemicals are often associated with the presence of glandular trichomes, at least in the case of 2-TD (Aragão et al., 2000a) and zingiberene (Maluf et al., 2001; Freitas et al., 2002). In genotypes derived from the wide cross L. esculentum $\mathrm{x}$ the 2-TDrich L. hirsutum var. glabratum PI 134417, high 2-TD levels were associated with glandular trichomes types IV and VI (Luckwill, 1943), especially the latter (Aragão et al., 2000a). The authors concluded that 2-TD is present type VI trichomes, and is largely responsible for spider mite resistance, which implied that either 2-TD contents or glandular trichome densities might be effectively used as indirect selection criteria for mite resistance/repellence. Contents of 2-TD are easily assessed by a colorimetric method (Barbosa \& Maluf, 1996; Aragão et al., 2000b) which is less time consuming than assessing trichome densities, and were therefore chosen as a criterion for selection for pest resistance in tomato (Barbosa \& Maluf, 1996; Labory, 1999). Selection of high 2-TD lines was fairly effective in generations not much removed from the original cross L. esculentum $\mathrm{x}$ L. hirsutum var. glabratum PI 134417; and improved lines (TOM-600, TOM-601, and others) were obtained with higher 2-TD levels, higher trichome densities, and resistance to the South American tomato pinworm (Labory et al., 1999), the silverleaf whitefly (Freitas et al., 2002) and spider mites Tetranychus urticae (Aragão et al., 2000a). However, levels of 2-TD and glandular trichome densities, in these improved lines, were not as high as in the wild accession PI 134417, due to the oligo or polygenic nature of inheritance (Barbosa \& Maluf, 1996), and the original sampling procedures (Aragão et al., 2000b) for 2-TD determination were no longer effective for selection, in populations derived from crosses with TOM-600/TOM-601.

The aim of this work was to evaluate the feasibility of selection for tomato's higher glandular trichome densities, as an indirect criterion of selection for increased repellence to spider mites Tetranychus urticae, in populations derived from the interspecific cross between Lycopersicon esculentum x L. hirsutum var. glabratum PI 134417.

\section{Material and Methods}

Initially, glandular and nonglandular trichomes were classified and quantified in several tomato genotypes, which included two segregating populations derived from a cross between cultivated L. esculentum and the wild accession L. hirsutum var. glabratum PI 134417. In sequence, plants were selected from the segregating populations based on their higher densities of glandular trichomes, and were used in bioassays with Tetranychus urticae, in order to determine correlation between levels of mite resistance (repellence) and densities of glandular trichomes.

Contrasting genotypes regarding their 2-TD levels and trichome densities were used in this study, and are described as follows: (a) TOM-584 - a standard low 2-TD mite-susceptible tomato line with indeterminate growth habit and barrel-shaped fruit (Santa Clara type), used as check treatment; (b) TOM-679 - a standard low 2-TD mite-susceptible tomato line with determinate growth habit, saladette-type fruit with jointless pedicels, used as check treatment; (c) PI 134417 - an accession of L. hirsutum var. glabratum, with high 2-TD levels, high 
trichome densities, and resistant to a wide array of tomato pests, including spider mites Tetranychus urticae; (d) TOM-600 - proprietary designation of the line previously described as BPX-318G20113-20-50-18 (Labory et al., 1999) and its subsequent selfings, with mid to high levels of 2-TD; line derived from the interspecific cross L.esculentum x L. hirsutum var. glabratum PI 134417, followed by two backcrosses to L. esculentum, with selection at each segregating generation for high 2-TD contents, reportedly resistant to the South American tomato pinworm (Labory et al., 1999), to the silverleaf whitefly Bemisia spp. (Freitas et al., 2002), and to spider mites Tetranychus urticae (Aragão et al., 2000a); (e) TOM-621, TOM-622: lines derived from different single plant selections of TOM600, with larger fruit sizes; (f) BPX-365D.... - F6 plants obtained from F5 lines derived from the cross between line BPX-339C004 (early designation of TOM-679) and TOM-600; in the segregating generations up to F6, selections were effected on the basis of higher density of glandular tricomes; it is expected that selections of pedigree BPX-365D would present higher glandular trichome densities than those of the standard check line TOM-679; (g) BPX-367B... - F4 plants obtained from F3 families derived from the cross between TOM-584 and TOM-600; in the segregating F2 and F4 generations, selections were effected on the basis of higher density of glandular trichomes; it is expected that selections of pedigree BPX367B would present higher glandular trichome densities than those of the standard check line TOM-584.

Genotypes screened for trichome densities included, besides TOM-584, TOM-679, PI 134417, TOM-600, TOM-621 and TOM-622, six lines of pedigree BPX365D (families BPX-365D 751-10-01, BPX-365D 75105-02, BPX-365D 751-05-01, BPX-365D 899-07-04, BPX-365D 986-09-05, BPX-365D 986-14-02), and seven lines of pedigree BPX-367B (families BPX-367B pl\#007, BPX-367B pl\#074, BPX-367B pl\#147, BPX-367B pl\#151, BPX-367B pl\#207, BPX-367B pl\#238, BPX367B pl\#246).

Lines were sown on August 10, 2006 on 128-cell styrofoam speedling trays filled with artificial sowing mix Plantimax + carbonized rice husks (proportion $1: 1 \mathrm{v} / \mathrm{v}$ ), and were kept in a plastic-covered greenhouse at HortiAgro Sementes Research Station

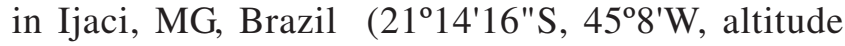
$918 \mathrm{~m}$ ). The sowing date for PI 134417 was seven days earlier, accounting for the slower germination rate of this accession.
The experimental design was a randomized complete block design with four blocks, 19 genotypes, and two plants per genotype per block, totaling 152 plants (of which 148 survived to be evaluated). Seedlings were transplanted into 500-mL plastic pots. On September 5, 2006, one leaflet was sampled from the mid-third portion of each plant, and placed in a plastic vial with $70 \%$ ethanol, where it was kept completely submerged until it was used for trichome counts. Paradermic preparations were taken from both the adaxial and abaxial faces of the leaflet, and placed in Petri dishes with 1:1 v/v water/ commercial sodium hypochloride (5\%). After a few minutes, the solution was removed and the preparations were rinsed with distilled water. Semipermanent slides were prepared, after coloring the peridermic preparations with safranine $0.1 \%$ in glicerine-water $1: 1$. A stereomicroscope $(40 \mathrm{X})$ with viewing field of known dimensions was used in order to evaluate trichome densities. Three fields per preparation were used to estimate trichome densities, which were expressed as numbers of trichomes per square centimetre leaf area.

Trichomes were classified based on their morphology and on the presence or absence of glandular trichomes (Luckwill, 1943). Trichomes types IV and VI were counted separately, but counts of other glandular trichomes (types I and VII) were pooled together as "other glandular types". Similarly, counts of all types of nonglandular trichomes (types I, III and V) were also pooled together.

Out of the 148 plants screened for trichome densities, 37 plants were selected, which included 14 single plant selections of the pedigree BPX-365D and 7 single plant selections of pedigree BPX-367B, besides the check treatments TOM-584 (two plants), TOM-679 (three plants), PI 134417 (two plants), TOM-600 (two plants), TOM-621 (five plants) e TOM-622 (two plants). The plants selected from BPX-365D and BPX-367B were chosen, based on their higher trichome densities relative to their respective mean populations. These plants were maintained as clones (via rooting of axillary shoots), and reserved for the mite repellence bioassay.

Due to limitations of space, mite populations and plant material (fully expanded non-senescent tomato leaflets), only a sample of 22 out of 37 plants were actually used in the mite repellence test, and they included 12 single-plant selections from populations BPX-365 or BPX-367B, which were identified as follows: BPX-365D 751-10-01 pl\#01, BPX-365D 751-10-01 pl\#02, BPX-365D 751-05-02 pl\#02, 
BPX-365D 751-05-01 pl\#03, BPX-365D 986-14-02 pl\#03, BPX-365D 986-14-02 pl\#04, BPX-365D 899-07-04 pl\#02, BPX-367B 238 pl\#02, BPX-367B 207 pl\#01, BPX-367B 151 pl\#02, BPX-367B 074 pl\#02, BPX-367B 007 pl\#03.

Plants used as checks in the mite bioassay included treatments TOM-600 (one plant), TOM-621 (two plants), TOM-622 (one plant), TOM-584 (two plants), TOM-679 (two plants) and PI 134417 (two plants). TOM-584, a standard commercial line susceptible to pests, was used as recurrent parent in backcrosses to obtain BPX-367B, and was therefore used in comparisons with genotypes of the latter, in evaluations of trichome densities, as well as in the mite repellence bioassay. Similarly, TOM-679 was used as recurrent parent in backcrosses to obtain BPX-365D, and was used in comparisons with genotypes selected from that population.

Spider mites Tetranychus urticae were obtained from infested bean Phaseolus vulgaris plants, available at HortiAgro Sementes Research Station in Ijaci, MG, Brazil, in March 2007. The mite resistance biossay was conducted according to Weston \& Snyder (1990). Fully expanded leaflets from the upper-third portion were collected from each plant to be tested. Leaflets were nailed with a metallic thumbtack onto a sheet of A4 printing paper placed onto a styrofoam sheet. The repellence test was carried out in a chamber at $18^{\circ} \mathrm{C}$ and $57 \%$ relative humidity. Ten females of Tetranychus urticae mites were placed on each thumbtack, and distances traveled by mites onto the leaf surface were recorded after 20, 40 and $60 \mathrm{~min}$. Mites found outside the limits of the leaflet were considered to have traveled as much as the mite found farther from the edge of the thumbtack. Mites that would be on the thumbtack, after the period considered, had their traveled distances recorded as zero. Lower distances traveled by mites are indicative of higher levels of mite resistance (repellence). In order to integrate traveled distance data measured at 20, 40 and $60 \mathrm{~min}$, an additional parameter was considered, i.e., the area under the curve distances walked $\mathrm{x}$ time, measured from 0 to $60 \mathrm{~min}$. Lower areas under the curve are indicative of higher levels of mite resistance.

\section{Results and Discussion}

In all genotypes under study, the most frequent glandular trichome was type VI, both in the abaxial and adaxial surfaces (Table 1). The wild L. hirsutum var. glabratum PI 134417 had the highest glandular trichome densities, in both the abaxial and adaxial surfaces, in accordance to the expected hirsute nature of this accession and with the findings of Aragão et al. (2000a). The arthropod susceptible standard line TOM584 had the lowest glandular trichome densities in both leaf surfaces (Table 1).

Table 1. Mean densities (number $\mathrm{cm}^{-2}$ ) of glandular trichomes and their amplitudes (between parenthesis) in the genotypes ${ }^{(1)}$.

\begin{tabular}{|c|c|c|c|c|c|c|c|c|}
\hline \multirow{2}{*}{$\begin{array}{l}\text { Tomato } \\
\text { genoytpe/ } \\
\text { population }\end{array}$} & \multirow{2}{*}{$\begin{array}{c}\text { No. of plants } \\
\text { evaluated }\end{array}$} & \multicolumn{3}{|c|}{ Abaxial surface } & \multicolumn{3}{|c|}{ Adaxial surface } & \multirow{2}{*}{$\begin{array}{c}\text { Mean density } \\
\text { (abaxial+adaxial) } \\
\text { glandular } \\
\text { trichomes }\end{array}$} \\
\hline & & $\begin{array}{l}\text { Type IV } \\
\text { trichomes }\end{array}$ & $\begin{array}{c}\text { Type VI } \\
\text { trichomes }\end{array}$ & $\begin{array}{c}\text { Total glandular } \\
\text { trichomes }^{(2)}\end{array}$ & $\begin{array}{l}\text { Type IV } \\
\text { trichomes }\end{array}$ & $\begin{array}{l}\text { Type VI } \\
\text { trichomes }\end{array}$ & $\begin{array}{l}\text { Total glandular } \\
\text { trichomes }\end{array}$ & \\
\hline TOM-679 & 8 & $0.0 \mathrm{a}$ & $\begin{array}{c}925.0 \mathrm{~b} \\
(0-1,973.3)\end{array}$ & $\begin{array}{c}986.7 \mathrm{~b} \\
(0-1,973.3)\end{array}$ & $0.0 \mathrm{a}$ & $\begin{array}{c}863.3 c \\
(0-2,466.7)\end{array}$ & $\begin{array}{c}986.7 b \\
(493.3-2,466.7)\end{array}$ & $\begin{array}{c}986.7 b \\
(246.7-1,973.3)\end{array}$ \\
\hline PI 134417 & 8 & $\begin{array}{c}308.3 a \\
(0-2,466.7)\end{array}$ & $\begin{array}{c}8,941.7 \mathrm{a} \\
(4,933.3-11,840)\end{array}$ & $\begin{array}{c}9,250.0 \mathrm{a} \\
(7,400-11,840)\end{array}$ & $0.0 \mathrm{a}$ & $\begin{array}{c}6,166.7 \mathrm{a} \\
(3,453.3-7,893.3)\end{array}$ & $\begin{array}{c}6,228.3 \mathrm{a} \\
(3,453.3-7,893.3)\end{array}$ & $\begin{array}{c}7,739.2 \mathrm{a} \\
(5,426.7-9,620)\end{array}$ \\
\hline TOM-600 & 8 & $0.0 \mathrm{a}$ & $\begin{array}{c}863.3 \mathrm{~b} \\
(493.3-1,480)\end{array}$ & $\begin{array}{c}925.0 \mathrm{~b} \\
(493.3-1,480)\end{array}$ & $0.0 \mathrm{a}$ & $\begin{array}{c}678.3 \mathrm{c} \\
(493.3-986.7)\end{array}$ & $\begin{array}{c}863.3 b \\
(493.3-986.7)\end{array}$ & $\begin{array}{c}894.2 b \\
(493.3-1,233.3)\end{array}$ \\
\hline TOM-621 & 8 & $0.0 \mathrm{a}$ & $\begin{array}{c}1,048.3 b \\
(493.3-2,466.7)\end{array}$ & $\begin{array}{c}1,048.3 b \\
(493.3-2,466.7)\end{array}$ & $0.0 \mathrm{a}$ & $\begin{array}{c}1,480.0 \mathrm{~b} \\
(986.7-2,466.7)\end{array}$ & $\begin{array}{c}1,788.3 b \\
(986.7-2,960)\end{array}$ & $\begin{array}{c}1,418.3 b \\
(740-2,220)\end{array}$ \\
\hline TOM-622 & 8 & $0.0 \mathrm{a}$ & $\begin{array}{c}616.7 \mathrm{c} \\
(0-1,480)\end{array}$ & $\begin{array}{c}678.3 \mathrm{bc} \\
(0-1,480)\end{array}$ & $0.0 \mathrm{a}$ & $\begin{array}{c}678.3 \mathrm{c} \\
(0-1,480)\end{array}$ & $\begin{array}{c}863.3 \mathrm{~b} \\
(0-1,480)\end{array}$ & $\begin{array}{c}770.8 \mathrm{bc} \\
(0-1,233.3)\end{array}$ \\
\hline $\mathrm{BPX}-365 \mathrm{D}^{(3)}$ & 48 & $\begin{array}{c}10.3 \mathrm{a} \\
(0-493.3)\end{array}$ & $\begin{array}{c}966.1 \mathrm{~b} \\
(0-3,946.7)\end{array}$ & $\begin{array}{c}1,110.0 \mathrm{~b} \\
(0-3,946.7)\end{array}$ & $0.0 \mathrm{a}$ & $\begin{array}{c}678.3 \mathrm{c} \\
(0-1,973.3)\end{array}$ & $\begin{array}{c}976.4 b \\
(0-2,466.7)\end{array}$ & $\begin{array}{c}1,043.2 b \\
(246.7-2,466.7)\end{array}$ \\
\hline
\end{tabular}

(1) Means followed by equal letters within a column do not differ from each other by the t test $(\alpha=0.05)$; numbers within parenthesis indicate amplitude of values found among plants within genotypes. ${ }^{(2)}$ Total density of glandular trichomes (types I+IV+VI+VII). ${ }^{(3)}$ Set of six families: BPX-365D 751-10-01, BPX-365D 751-05-02, BPX-365D 751-05-01, BPX-365D 899-07-04, BPX-365D 986-09-05, BPX-365D 986-14-02. (4)Set of seven families: BPX-367B pl\#007, BPX-367B pl\#074, BPX-367B pl\#147, BPX-367B pl\#151, BPX-367B pl\#207, BPX-367B pl\#238, BPX-367B pl\#246. 
Based on higher densities of type IV and total glandular trichomes, 14 plants were selected from population BPX-365D, and seven from population BPX-367B (Table 2). These plants were cloned (via rooting of axillary shoot cuttings), and thus maintained in greenhouse pots for further tests, along with plants of TOM-584 (two plants), TOM-679 (three plants), PI 134417 (two plants), TOM-600 (two plants), TOM-621 (five plants) and TOM-622 (two plants) (Table 2).

A few plants within BPX-365D and BPX-367D that stood out because of their trichome counts higher than their respective checks, TOM-679 and TOM-584, were selected (Table 3 ) for further testing in the mite repellence thumbtack assay. The total of plants selected was seven within population BPX365D and five within population BPX-367B (Table 3), and they were maintained via rooted axillary cuttings until further tests for mite repellence along with check treatments TOM-584 (two clones), TOM-679 (two clones), PI 134417 (two clones), TOM-600 (one clone), TOM-621 (two clones) and TOM-622 (one clone). These selected genotypes showed a null density of type VI glandular trichomes, and with a few exceptions they showed no other type of glandular trichome except for type VI (Table 3). Therefore, type VI trichomes represented the near total of glandular trichomes found. Nonglandular trichomes varied widely in density among the genotypes
(Table 3), but they are not relevant for arthropod resistance: the wild accession PI 134417, known to be highly resistant to a wide array of tomato pests (Maluf et al., 1997; Gonçalves et al., 1998), had the lowest nonglandular trichome densities among the genotypes surveyed (Table 3 ).

Taking into account the mean density of glandular trichomes, in both leaf surfaces, improved line BPX365D 899-07-04 pl\#02 (2466.7 glandular trichomes $\mathrm{cm}^{-2}$ ) was the only one which significantly outperformed the check TOM-584 (123.3 glandular trichomes $\mathrm{cm}^{-2}$ ), by Tukey's multiple range test $(\alpha=0,05)$. However, because PI 134417, a treatment with substantially higher density of glandular trichomes $\left(9,126.7 \mathrm{~cm}^{-2}\right)$, was included in the trial, Tukey's multiple range test may not have been able to detect biologically important differences among the other treatments, whose mean glandular trichome densities lie in a much lower range (123.3 to 2466.7 glandular trichomes $\mathrm{cm}^{-2}$ ). The biological significance of the numerically higher glandular trichome densities found in lines such as BPX-365D 89907-04 pl\#02, BPX-365D 751-05-02 pl\#02 or BPX-365D 986-14-02 pl\#04, lines related to their recurrent parent TOM-679, or in all BPX-367B lines related to their recurrent counterpart TOM-584 (Table 3), remains to be uncovered by the mite repellence test.

There were significant differences ( $F$ test, $\alpha=0.05$ ) among genotypes for distances walked by T. urticae

Table 2. Mean densities (number $\mathrm{cm}^{-2}$ ) of glandular trichomes, in the set of 37 single plants chosen from the original set of 148 plants, after selection for higher densities of total glandular trichomes within populations BPX-365D and BPX-367B ${ }^{(1)}$.

\begin{tabular}{|c|c|c|c|c|c|c|c|c|}
\hline \multirow{2}{*}{$\begin{array}{l}\text { Tomato } \\
\text { genoytpe/ } \\
\text { population }\end{array}$} & \multirow{2}{*}{$\begin{array}{l}\text { No. of plants } \\
\text { selected }\end{array}$} & \multicolumn{3}{|c|}{ Abaxial leaf surface } & \multicolumn{3}{|c|}{ Adaxial leaf surface } & \multirow{2}{*}{$\begin{array}{c}\text { Mean density } \\
\text { (abaxial+adaxial) } \\
\text { glandular trichomes }\end{array}$} \\
\hline & & $\begin{array}{c}\text { Total glandular } \\
\text { trichomes }\end{array}$ & $\begin{array}{l}\text { Type VI } \\
\text { trichomes }\end{array}$ & $\begin{array}{l}\text { Total glandular } \\
\text { trichomes }^{(2)}\end{array}$ & $\begin{array}{l}\text { Type IV } \\
\text { trichomes }\end{array}$ & $\begin{array}{l}\text { Type VI } \\
\text { trichomes }\end{array}$ & $\begin{array}{c}\text { Total glandular } \\
\text { trichomes }\end{array}$ & \\
\hline TOM-584 & 2 & 0.0 & 0.0 & 0.0 & 0.0 & $\begin{array}{c}246.7 \\
(0-493.3)\end{array}$ & $\begin{array}{c}246.7 \\
(0-493.3)\end{array}$ & $\begin{array}{c}123.3 \\
(0-246.7)\end{array}$ \\
\hline TOM-679 & 3 & 0.0 & $\begin{array}{c}1,315.6 \\
(493.3-1,973.3)\end{array}$ & $\begin{array}{c}1,315.6 \\
(493.3-1,973.3)\end{array}$ & 0.0 & $\begin{array}{c}1,480.0 \\
(493.3-2,466.7)\end{array}$ & $\begin{array}{c}1,644.4 \\
(493.3-2,466.7)\end{array}$ & $\begin{array}{c}1,480.0 \\
(986.7-1,973.3)\end{array}$ \\
\hline PI 134417 & 2 & 0.0 & $\begin{array}{c}11,100.0 \\
(10,360-11,840)\end{array}$ & $\begin{array}{c}11,100.0 \\
(10,360-11,840)\end{array}$ & 0.0 & $\begin{array}{c}6,906.7 \\
(6,906.7-6,906.7)\end{array}$ & $\begin{array}{c}7,153.3 \\
(6,906.7-7,400)\end{array}$ & $\begin{array}{c}9,126.7 \\
(8,633.3-9,620)\end{array}$ \\
\hline TOM-600 & 2 & 0.0 & $\begin{array}{c}986.7 \\
(493.3-1,480)\end{array}$ & $\begin{array}{c}1,233.3 \\
(986.7-1,480)\end{array}$ & 0.0 & $\begin{array}{c}740.0 \\
(493.3-986.7)\end{array}$ & $\begin{array}{c}986.7 \\
(986.7-986.7)\end{array}$ & $\begin{array}{c}1,110.0 \\
(986.7-1,233.3)\end{array}$ \\
\hline TOM-621 & 5 & 0.0 & $\begin{array}{c}1,282.7 \\
(493.3-2,466.7)\end{array}$ & $\begin{array}{c}1,282.7 \\
(493.3-2,466.7)\end{array}$ & 0.0 & $\begin{array}{c}1,677.3 \\
(986.7-2,466.7)\end{array}$ & $\begin{array}{c}2,170.7 \\
(986.7-2,960)\end{array}$ & $\begin{array}{c}1,726.7 \\
(1,233.3-2,220)\end{array}$ \\
\hline TOM-622 & 2 & 0.0 & $\begin{array}{c}1,233.3 \\
(986.7-1,480)\end{array}$ & $\begin{array}{c}1,233.3 \\
(986.7-1,480)\end{array}$ & 0.0 & $\begin{array}{c}740.0 \\
(493.3-986.7)\end{array}$ & $\begin{array}{c}986.7 \\
(986.7-986.7)\end{array}$ & $\begin{array}{c}1,110.0 \\
(986.7-1,233.4)\end{array}$ \\
\hline $\mathrm{BPX}-365 \mathrm{D}^{(3)}$ & 14 & 0.0 & $\begin{array}{c}1,761.9 \\
(986.7-3,946.7)\end{array}$ & $\begin{array}{c}1,938.1 \\
(986.7-3,946.7)\end{array}$ & 0.0 & $\begin{array}{c}1,127.6 \\
(0-1,973.3)\end{array}$ & $\begin{array}{c}1,480.0 \\
(493.3-2,466.7)\end{array}$ & $\begin{array}{c}1,709.0 \\
(1,233.3-2,466.7)\end{array}$ \\
\hline BPX-367B ${ }^{(4)}$ & 7 & 0.0 & $\begin{array}{c}1,057.1 \\
(0-1,973.3) \\
\end{array}$ & $\begin{array}{c}1,268.6 \\
(493.3-1,973.3) \\
\end{array}$ & 0.0 & $\begin{array}{c}916.2 \\
(0-1,480) \\
\end{array}$ & $\begin{array}{c}1,480.0 \\
(986.7-2,466.7) \\
\end{array}$ & $\begin{array}{c}1,374.3 \\
(1,233.3-1,480) \\
\end{array}$ \\
\hline
\end{tabular}

(1)Numbers within parenthesis indicate amplitude of values found among plants within genotypes. ${ }^{(2)}$ Total density of glandular trichomes (types I+IV+VI+VII). ${ }^{(3)}$ Set of 14 single plant selections. ${ }^{(4)}$ Set of seven single plant selections. 


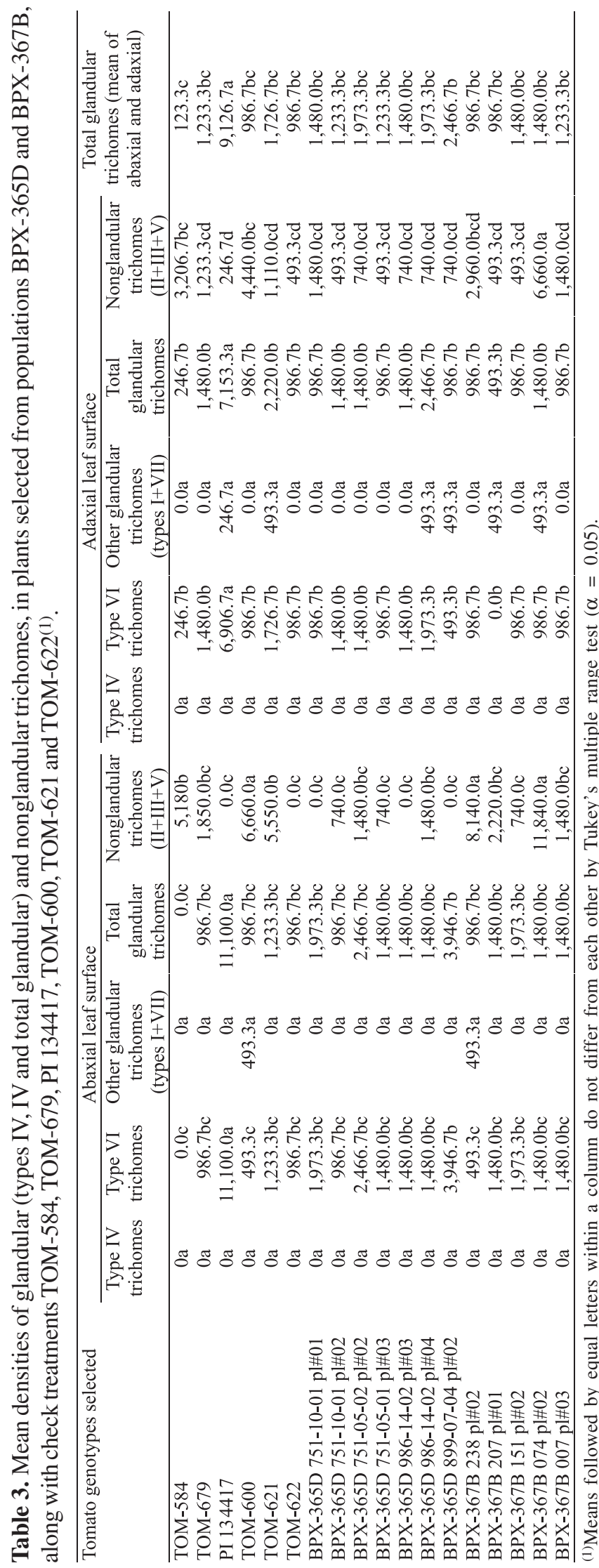

onto the leaf surface after 20,40 and $60 \mathrm{~min}$, and for the areas under the curve distances walked $\mathrm{x}$ time (Table 4).

The shortest distances traveled by the mites and the smallest area under the curve were those presented by PI 134417, confirming the highest level of mite repellence of this wild accession, when compared with all other genotypes tested (Tables 5 and 6). The commercial check line TOM-584 showed the longest distances traveled by the mites, as well as the largest area under the curve, and can be considered the most susceptible genotype. TOM-679 was also considered one of the most susceptible genotypes, and its susceptibility was evident, particularly when compared to data obtained for BPX-365D, whose genotypic background is similar (Tables 5 and 6).

All five genotypes selected from population BPX-367B, as well as the seven ones selected from BPX-365D, were more repellent to mites than the check TOM-584, especially in relation to mean distances traveled after $40 \mathrm{~min}$ or more (Tables 5 and 6). These differences were less evident relatively to the check TOM-679 (Table 6), which, although considered mite susceptible, has a higher glandular trichome density than TOM-584 (Table 3). Four genotypes from population BPX-365D - BPX-365D 751-0502 pl\#02, BPX-365D 751-05-01 pl\#03, BPX-365D 751-14-02 pl\#04, BPX-365D 751-07-04 pl\#02 -, and two lines from BPX-367B - BPX-367B 207 pl\#01 and BPX-367B 007 pl\#03 - were nonetheless more repellent to mites than TOM-679 itself, as measured by the area under the curve (Table 6).

Estimates of contrasts between TOM-584 and related background BPX-367B lines indicated significant differences $(\alpha=0.01)$ by the F test, in the distances $(\mathrm{mm})$ traveled by mites at 20,40 and $60 \mathrm{~min}$ and in the areas ( $\mathrm{mm} \times \mathrm{min}$ ) under the curve (Table 6). Analogous differences at $\alpha=0.01$ were found between TOM-679 and BPX-365D lines with related genotypic background (Table 6). The significance of these contrasts indicate that selection based on higher densities of glandular trichomes effectively increased levels of mite resistance (repellence) in tomato lines.

Mite repellence levels of PI 134417 were higher than those found in populations BPX-365D and BPX-367B, whose mite resistance levels, regarding to the commercial checks, were obtained from the former wild accession (Table 6). This indicates that, even though 2-tridecanone and glandular trichomes might contribute significantly to impart mite resistance (repellence), they are not the sole factors responsible for the high levels of 
mite resistance in PI 134417. Despite this fact, a few selected genotypes (BPX-365D 751-05-02 pl\#02 and BPX-365D 986-14-02 pl\#04), particularly after 20 and 40 min after mite infestation, showed levels of mite repellence similar to those found in PI 134417 (Table 6).

Considering all genotypes under study, there were significant negative correlations between densities of glandular trichomes and mite repellence levels (Table 7). These correlations varied between -0.56 and -0.71 (Table 7), for all traits under consideration, for type VI and total glandular trichome densities, both in adaxial and abaxial leaf surfaces. Type IV trichomes were absent in the selected genotypes, a fact that led to null correlation estimates. Snyder \& Carter (1984) report the association of type VI trichomes in L. hirsutum and spider mite resistance, a conclusion compatible with the results of the present study.

Because the wild accession L.hirsutum var. glabratum PI 134417 is an exotic germplasm, and it shows glandular trichome densities that could not be fully recovered after backcrosses to L. esculentum, it was excluded from calculations of another set of correlation coefficients which included all the other genotypes. In this case, significant negative correlation coefficients were found between glandular (type VI and total) trichome densities in the abaxial surface and distances traveled by the mites (Table 7), even though correlation coefficients were not significant when adaxial trichome counts were considered. A similar pattern of significance of correlation coefficients was found, when they were calculated between TOM-584 and its related BPX-367B lines, or between TOM-679 and its related BPX-365D lines (Table 7). The results indicated that a higher glandular trichome density is indeed associated with higher repellence to spider mites T. urticae,

Table 4. Analysis of variance for the distances walked by T. urticae onto the leaf surface after 20,40 and $60 \mathrm{~min}$, and for areas under the curve distances walked $\mathrm{x}$ time, measured from 0 to $60 \mathrm{~min}$.

\begin{tabular}{|c|c|c|c|c|c|}
\hline \multirow[t]{3}{*}{ Source of variation } & \multirow[t]{3}{*}{$\mathrm{df}$} & \multicolumn{4}{|c|}{ Sums of squares } \\
\hline & & \multicolumn{3}{|c|}{ Distances $(\mathrm{mm})$ walked after } & \multirow{2}{*}{$\begin{array}{l}\text { Areas under } \\
\text { curve } \\
(\mathrm{mm} \times \mathrm{min})\end{array}$} \\
\hline & & $20 \mathrm{~min}$ & $40 \min$ & $60 \mathrm{~min}$ & \\
\hline Blocks & 4 & $14.460 *$ & $36.078 * *$ & $28.835^{* *}$ & $60,424.190 * *$ \\
\hline Genotypes & 17 & $40.508^{* *}$ & $53.496 * *$ & $51.175^{* *}$ & $114,797.033 * *$ \\
\hline Plants within genotypes & 4 & $3.453^{\mathrm{ns}}$ & $3.176^{\mathrm{ns}}$ & $8.557^{\mathrm{ns}}$ & $7,680.325^{\mathrm{ns}}$ \\
\hline Residual & 84 & 4.486 & 5.000 & 4.000 & 8.021 \\
\hline
\end{tabular}

particularly for trichome counts made in the abaxial leaf surface. The slack association found with trichome counts, in the adaxial leaf surface, can be accounted for the usually lower trichome densities found in it, related to counts made in the abaxial face (Table 3 ), and reinforces the conclusion that mite repellence is mediated by high glandular trichome counts.

The genotypes were selected in this work on the basis of higher densities of glandular (particularly type VI) trichomes, whose glands are reported to possess high levels of 2-tridecanone (Dimock \& Kennedy, 1983). They showed also higher levels of repellence to Tetranychus urticae, confirming previous reports by Gonçalves et al. (1998) and Aragão et al. (2000a), in less advanced tomato generations. Genotypes selected for higher glandular trichome densities showed generally lower distances traveled by mites onto their leaf surface than the standard tomato check lines, TOM-584 and TOM-679, and are therefore considered more resistant to mites. A few of the selected genotypes showed repellence levels close to those shown by the wild accession PI 134417. Given the current difficulty found in sampling procedures, used to screen directly the high 2-tridecanone contents, selection for high glandular trichome densities may constitute an efficient alternative tool of selection for spider mite repellence.

Table 5. Least square genotype means ${ }^{(1)}$ for the distances (mm) walked by $T$. urticae onto the leaf surface after 20, 40 and $60 \mathrm{~min}$, and for areas under the curve distances walked $\mathrm{x}$ time, measured from 0 to $60 \mathrm{~min}$.

\begin{tabular}{|c|c|c|c|c|}
\hline \multirow[t]{2}{*}{ Genotype } & \multicolumn{3}{|c|}{$\begin{array}{c}\text { Distances }(\mathrm{mm}) \text { walked } \\
\text { after }\end{array}$} & \multirow{2}{*}{$\begin{array}{l}\text { Areas under } \\
\text { curve } \\
(\mathrm{mm} \times \mathrm{min})\end{array}$} \\
\hline & $20 \mathrm{~min}$ & $40 \mathrm{~min}$ & $60 \mathrm{~min}$ & \\
\hline TOM-584 & 14.31 & 17.51 & 19.22 & 829 \\
\hline TOM-679 & 12.69 & 13.96 & 15.22 & 685 \\
\hline PI 134417 & 5.35 & 6.60 & 8.07 & 320 \\
\hline TOM-600 & 14.22 & 17.50 & 18.10 & 815 \\
\hline TOM-621 & 11.11 & 13.48 & 15.90 & 651 \\
\hline TOM-622 & 10.34 & 14.92 & 15.46 & 660 \\
\hline BPX-365D 751-10-01 pl\#01 & 12.36 & 13.62 & 14.46 & 664 \\
\hline BPX-365D 751-10-01 pl\#02 & 10.80 & 11.52 & 13.08 & 577 \\
\hline BPX-365D 751-05-02 pl\#02 & 7.16 & 9.68 & 13.42 & 471 \\
\hline BPX-365D 751-05-01 pl\#03 & 9.44 & 11.08 & 12.02 & 531 \\
\hline BPX-365D 986-14-02 pl\#03 & 9.08 & 11.90 & 14.04 & 560 \\
\hline BPX-365D 986-14-02 pl\#04 & 8.24 & 10.64 & 11.46 & 492 \\
\hline BPX-365D 899-07-04 pl\#02 & 9.00 & 11.20 & 13.42 & 538 \\
\hline BPX-367B 238 pl\#02 & 11.68 & 12.70 & 15.38 & 641 \\
\hline BPX-367B 207 pl\#01 & 9.14 & 10.14 & 12.66 & 512 \\
\hline BPX-367B $151 \mathrm{pl} \# 02$ & 10.86 & 12.42 & 14.42 & 610 \\
\hline BPX-367B 074 pl\#02 & 9.50 & 11.94 & 14.38 & 573 \\
\hline BPX-367B 007 pl\#03 & 8.96 & 11.28 & 11.92 & 524 \\
\hline
\end{tabular}

${ }^{(1)}$ Tests $(\alpha=0.05)$ for comparisons of genotype means with check treatments TOM-584, TOM-679 e PI 134417 are presented in Table 6. 
Table 6. F values for multiple comparisons among genotypes with check treatments TOM-584, TOM-679 and PI 134417, and contrasts among genotypes selected for high densities of glandular trichomes and their respective recurrent parents.

\begin{tabular}{|c|c|c|c|c|c|c|c|c|c|c|c|c|}
\hline \multirow[t]{3}{*}{ Genotype } & \multicolumn{9}{|c|}{ Distances walked after } & \multicolumn{3}{|c|}{ Areas under curve } \\
\hline & \multicolumn{3}{|c|}{$20 \mathrm{~min}$} & \multicolumn{3}{|c|}{$40 \mathrm{~min}$} & \multicolumn{3}{|c|}{$60 \mathrm{~min}$} & \multicolumn{3}{|c|}{$(\mathrm{mm} \times \mathrm{min})$} \\
\hline & $\begin{array}{c}\text { Test } \\
\text { prob. } \\
<\text { TOM } 584\end{array}$ & $\begin{array}{c}\text { Test } \\
\text { prob. } \\
<\text { TOM679 }\end{array}$ & $\begin{array}{c}\text { Test } \\
\text { prob } \\
>\text { PI } 134417\end{array}$ & $\begin{array}{c}\text { Test } \\
\text { prob. } \\
<\text { TOM } 584\end{array}$ & $\begin{array}{c}\text { Test } \\
\text { prob. } \\
<\text { TOM679 }\end{array}$ & $\begin{array}{c}\text { Test } \\
\text { prob } \\
>\text { PI } 134417\end{array}$ & $\begin{array}{c}\text { Test } \\
\text { prob. } \\
<\text { TOM } 584\end{array}$ & $\begin{array}{c}\text { Test } \\
\text { prob. } \\
<\text { TOM679 }\end{array}$ & $\begin{array}{c}\text { Test } \\
\text { prob } \\
>\text { PI } 134417\end{array}$ & $\begin{array}{c}\text { Test } \\
\text { prob. } \\
<\text { TOM } 584\end{array}$ & $\begin{array}{c}\text { Test } \\
\text { prob. } \\
<\text { TOM679 }\end{array}$ & $\begin{array}{c}\text { Test } \\
\text { prob } \\
\text { >PI } 134417\end{array}$ \\
\hline TOM-584 & - & $14.31^{\mathrm{ns}}$ & $14.31^{* *}$ & - & $17.51^{\mathrm{ns}}$ & $17.51^{* *}$ & - & $19.22^{\text {ns }}$ & $19.22 * *$ & - & $829^{\text {ns }}$ & $829 * *$ \\
\hline TOM-679 & $12.69^{\text {ns }}$ & - & $12.69 * *$ & $13.96^{* *}$ & - & $13.96 * *$ & $15.22 * *$ & - & $15.22 * *$ & $685^{* *}$ & - & $685^{* *}$ \\
\hline PI 134417 & $5.35^{* *}$ & $5.35^{* *}$ & . & $6.60 * *$ & $6.60^{* *}$ & & $8.07^{* *}$ & $8.07 * *$ & . & $320^{* *}$ & $320^{* *}$ & - \\
\hline TOM-600 & $14.22^{\mathrm{ns}}$ & $14.22^{\text {ns }}$ & $14.22 * *$ & $17.50^{\text {ns }}$ & $17.50^{\text {ns }}$ & $17.50^{* *}$ & $18.10^{\mathrm{ns}}$ & $18.10^{\mathrm{ns}}$ & $18.10^{* *}$ & $815^{\text {ns }}$ & $815^{\text {ns }}$ & $815^{* *}$ \\
\hline TOM-621 & $11.11^{* *}$ & $11.11^{\mathrm{ns}}$ & $11.11^{* *}$ & $13.48 * *$ & $13.48^{\mathrm{ns}}$ & $13.48 * *$ & $15.90 * *$ & $15.90^{\text {ns }}$ & $15.90^{* *}$ & $651^{* *}$ & $651^{\mathrm{ns}}$ & $651 * *$ \\
\hline TOM-622 & $10.34 * *$ & $10.34^{\text {ns }}$ & $10.34 * *$ & $14.92^{\text {ns }}$ & $14.92^{\text {ns }}$ & $14.92 * *$ & $15.46^{* *}$ & $15.46^{\mathrm{ns}}$ & $15.46^{* *}$ & $660^{* *}$ & $660^{\text {ns }}$ & $660^{* *}$ \\
\hline BPX-365D 751-10-01 pl\#01 & $12.36^{\mathrm{ns}}$ & $12.36^{\mathrm{ns}}$ & $12.36^{* *}$ & $13.62 * *$ & $13.62^{\mathrm{ns}}$ & $13.62 * *$ & $14.46^{* *}$ & $14.46^{\mathrm{ns}}$ & $14.46^{* *}$ & $664 * *$ & $664^{\mathrm{ns}}$ & $664 * *$ \\
\hline BPX-365D 751-10-01 pl\#02 & $10.80^{*}$ & $10.80^{\text {ns }}$ & $10.80^{* *}$ & $11.52 * *$ & $11.52^{\mathrm{ns}}$ & $11.52 * *$ & $13.08^{* *}$ & $13.08^{\text {ns }}$ & $13.08^{* *}$ & $577 * *$ & $577^{\mathrm{ns}}$ & $577 * *$ \\
\hline BPX-365D 751-05-02 pl\#02 & $7.16^{* *}$ & $7.16^{* *}$ & $7.16^{\mathrm{ns}}$ & $9.68^{* *}$ & $9.68^{* *}$ & $9.68^{\text {ns }}$ & $13.42 * *$ & $13.42^{\text {ns }}$ & $13.42 * *$ & $471^{* *}$ & $471^{* *}$ & $471 *$ \\
\hline BPX-365D 751-05-01 pl \#03 & $9.44 * *$ & $9.44 *$ & $9.44 * *$ & $11.08^{* *}$ & $11.08^{\mathrm{ns}}$ & $11.08^{* *}$ & $12.02 * *$ & $12.02 *$ & $12.02 * *$ & $531 * *$ & $531^{*}$ & $531 * *$ \\
\hline BPX-365D 986-14-02 pl\#03 & $9.08^{* *}$ & $9.08^{*}$ & $9.08^{*}$ & $11.90^{* *}$ & $11.90^{\mathrm{ns}}$ & $11.90^{* *}$ & $14.04 * *$ & $14.04^{\mathrm{ns}}$ & $14.04 * *$ & $560^{* *}$ & $560^{\text {ns }}$ & $560^{* *}$ \\
\hline BPX-365D 986-14-02 pl\#04 & $8.24 * *$ & $8.24 * *$ & $8.24^{\mathrm{ns}}$ & $10.64 * *$ & $10.64 *$ & $10.64 * *$ & $11.46^{* *}$ & $11.46^{* *}$ & $11.46^{*}$ & $492 * *$ & $492 * *$ & $492 * *$ \\
\hline BPX-365D 899-07-04 pl\#02 & $9.00 * *$ & $9.00^{*}$ & $9.00 *$ & $11.20^{* *}$ & $11.20^{\mathrm{ns}}$ & $11.20^{* *}$ & $13.42 * *$ & $13.42^{\mathrm{ns}}$ & $13.42 * *$ & $538^{* *}$ & $538^{*}$ & $538 * *$ \\
\hline BPX-367B $238 \mathrm{pl} \# 02$ & $11.68^{\mathrm{ns}}$ & $11.68^{\mathrm{ns}}$ & $11.68^{* *}$ & $12.70^{* *}$ & $12.70^{\text {ns }}$ & $12.70^{* *}$ & $15.38^{* *}$ & $15.38^{\text {ns }}$ & $15.38^{* *}$ & $641^{* *}$ & $641^{\text {ns }}$ & $641 * *$ \\
\hline BPX-367B 207 pl\#01 & $9.14 * *$ & $9.14 *$ & 9.14* & $10.14 * *$ & $10.14 *$ & $10.14 *$ & $12.66^{* *}$ & $12.66^{\mathrm{ns}}$ & $12.66^{* *}$ & $512^{* *}$ & $512 * *$ & $512 * *$ \\
\hline BPX-367B 151 pl\#02 & $10.86^{*}$ & $10.86^{\mathrm{ns}}$ & $10.86^{* *}$ & $12.42 * *$ & $12.42^{\mathrm{ns}}$ & $12.42 * *$ & $14.42 * *$ & $14.42^{\text {ns }}$ & $14.42 * *$ & $610^{* *}$ & $610^{\text {ns }}$ & $610^{* *}$ \\
\hline BPX-367B 074 pl\#02 & $9.50 * *$ & $9.50 *$ & $9.50 * *$ & $11.94 * *$ & $11.94^{\mathrm{ns}}$ & $11.94 * *$ & $14.38 * *$ & $14.38^{\text {ns }}$ & $14.38 * *$ & $573 * *$ & $573^{\text {ns }}$ & $573 * *$ \\
\hline BPX-367B $007 \mathrm{pl} \# 03$ & $8.96^{* *}$ & $8.96^{*}$ & $8.96^{*}$ & $11.28 * *$ & $11.28^{\mathrm{ns}}$ & $11.28^{* *}$ & $11.92 * *$ & $11.92 *$ & $11.92 * *$ & $524 * *$ & $524 *$ & $524 * *$ \\
\hline Contrasts & & & & & & Contrast & ates & & & & & \\
\hline TOM-584 vs. BPX-367B & & $4.28^{* *}$ & & & $5.81 * *$ & & & $5.46^{* *}$ & & & $257^{* *}$ & \\
\hline TOM-679 vs. BPX-365D & & $3.24 * *$ & & & $2.58^{* *}$ & & & $2.09 * *$ & & & $138^{* *}$ & \\
\hline
\end{tabular}

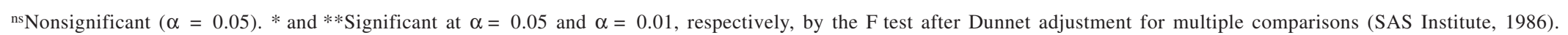

Table 7. Correlation coefficients between glandular trichome densities and distances walked by mites and areas under the curve mm $\mathrm{x}$ min, calculated with all genotypes tested; with all genotypes except PI 134417; with TOM-584 and BPX-367B only; and with TOM-679 and BPX-365D only.

\begin{tabular}{|c|c|c|c|c|c|c|c|c|c|c|c|c|c|c|c|c|}
\hline \multirow[t]{3}{*}{ Correlation coefficients $^{(1)}$} & \multicolumn{4}{|c|}{ All genotypes } & \multicolumn{4}{|c|}{$\begin{array}{l}\text { All genotypes but } \\
\text { PI } 134417 \\
\end{array}$} & \multicolumn{4}{|c|}{$\begin{array}{c}\text { TOM-584 and } \\
\text { BPX-367B }\end{array}$} & \multicolumn{4}{|c|}{$\begin{array}{l}\text { TOM-679 and } \\
\text { BPX-365D }\end{array}$} \\
\hline & \multicolumn{3}{|c|}{ Distances walked after } & \multirow{2}{*}{$\begin{array}{l}\text { Area } \\
\text { under } \\
\text { curve }\end{array}$} & \multicolumn{3}{|c|}{ Distances walked after } & \multirow{2}{*}{$\begin{array}{l}\text { Area } \\
\text { under } \\
\text { curve }\end{array}$} & \multicolumn{3}{|c|}{ Distances walked after } & \multirow{2}{*}{$\begin{array}{l}\text { Area } \\
\text { under } \\
\text { curve }\end{array}$} & \multicolumn{3}{|c|}{ Distances walked after } & \multirow{2}{*}{$\begin{array}{l}\text { Area } \\
\text { under } \\
\text { curve }\end{array}$} \\
\hline & $20 \mathrm{~min}$ & $40 \mathrm{~min}$ & $60 \mathrm{~min}$ & & & $40 \mathrm{~min}$ & $60 \mathrm{~min}$ & & $20 \mathrm{~min}$ & $40 \mathrm{~min}$ & $60 \mathrm{~min}$ & & $20 \mathrm{~min}$ & $40 \mathrm{~min}$ & $60 \mathrm{~min}$ & \\
\hline With 1 & 0 & 0.00 & 0.00 & 0.00 & 0 . & 0.00 & 0. & 0.00 & 0 . & 0.00 & 0 . & 0.00 & 0. & 0.00 & 0. & 0.00 \\
\hline With $t$ & -0.68 & -0.69 & -0.71 & -0.71 & -0.62 & -0.61 & -0.54 & -0.62 & -0.81 & -0.78 & -0.79 & -0.80 & -0.81 & -0.78 & -0.79 & -0.80 \\
\hline With total glandular trichomes ${ }^{(2)}-\mathrm{Ab}$ & -0.66 & -0.67 & -0.69 & -0.71 & -0.57 & -0.57 & -0.49 & -0.62 & -0.82 & -0.85 & -0.83 & -0.80 & -0.82 & -0.85 & -0.83 & -0.80 \\
\hline With type IV trichomes-Ad & 0. & 0.00 & 0.00 & 0.00 & 0.00 & 0.00 & 0.00 & 0.00 & 0.00 & 0.00 & 0.00 & 0.00 & 0.00 & 0.00 & 0.00 & 0.00 \\
\hline With type VI trichomes-Ad & -0.56 & -0.56 & -0.62 & -0.59 & -0.22 & -0.19 & -0.24 & -0.22 & -0.23 & -0.19 & -0.24 & -0.22 & -0.23 & -0.19 & -0.24 & -0.22 \\
\hline With total gla & -0.60 & -0.60 & -0.65 & -0.63 & -0.36 & -0.32 & -0.33 & -0.35 & -0.55 & -0.49 & 0.45 & -0.51 & -0.55 & -0.49 & -0.45 & -0.51 \\
\hline With total glandular tri & -0.65 & -0.66 & -0.69 & -0.68 & -0.65 & -0.62 & -0.56 & -0.64 & -0.79 & -0.78 & -0.75 & -0.79 & -0.79 & -0.78 & -0.75 & -0.79 \\
\hline
\end{tabular}

${ }^{(1)} \mathrm{Ab}=$ abaxial leaf surface; $\mathrm{Ad}=$ adaxial leaf surface. ${ }^{(2)}$ Total glandular trichomes = types $\mathrm{I}+\mathrm{IV}+\mathrm{VI}+\mathrm{VII}$. 


\section{Conclusions}

1. High densities of glandular trichomes (particularly type VI) are associated with higher levels of spider mite (T. urticae) repellence, in germplasm derived from L. hirsutum var. glabratum accession PI 134417.

2. Selection for higher trichome densities is effective to obtain lines with increased resistance to spider mites T. urticae.

3. Selection for high glandular trichome densities may substitute selection for high 2-tridecanone contents as an efficient tool of selection for spider mite repellence.

\section{Acknowlegements}

To CNPq, Fapemig, Ufla, Faepe/Ufla, Fundecc/Ufla, Capes/MEC, and HortiAgro Sementes Ltda.

\section{References}

ARAGÃO, C.A.; CARDOSO, M.G.; MALUF, W.R.; DANTAS, B.F. Método colorimétrico para determinação de 2-tridecanona (2-TD) em folíolos de tomateiro. Ciência eAgrotecnologia, v.24, p.105-109, 2000 b.

ARAGÃO, C.A.; MALUF, W.R.; DANTAS, B.F.; GAVILANES, M.L.; CARDOSO, M.G. Tricomas foliares associados à resistência ao ácaro rajado (Tetranychus urticae Koch.) em linhagens de tomateiro com alto teor de 2-tridecanona nos folíolos. Ciência e Agrotecnologia, v.24, p.81-93, 2000a.

AZEVEDO, S.M.; FARIA, M.V.; MALUF, W.R.; OLIVEIRA, A.C.B.; FREITAS, J.A. Zingiberene-mediated resistance to the South American tomato pinworm derived from Lycopersicon hirsutum var. hirsutum. Euphytica, v.134, p.347-351, 2003.

BARBOSA, L.V.; MALUF, W.R. Heritability of 2-tridecanonemediated arthropod resistance in an interspecific segregating generation of tomato. Revista Brasileira de Genética, v.19, p.465-468, 1996. DIMOCK, M.B.; KENNEDY, G.G. The role of glandular trichomes in the resistance of L. hirsutum f. glabratum to H. zea. Entomologia Experimentalis et Applicata, v.33, p.263-268, 1983.

EIGENBRODE, S.D.; TRUMBLE, J.T.; MILLAR, J.G.; WHITE, K.K. Topical toxicity of tomato sesquiterpenes to the beet armyworm and the role of these compounds in resistance derived from an accession of Lycopersicon hirsutum f. typicum. Journal of Agriculture and Food Chemistry, v.42, p.807-810, 1994.

FREITAS, J.A.; MALUF, W.R.; CARDOSO, M.G.; GOMES, L.A.A.; BEARZOTTI, E. Inheritance of foliar zingiberene contents and their relationship to trichome densities and whitefly resistance in tomatoes. Euphytica, v.127, p.275-287, 2002.

GENTILE, A.G.; WEBB, R.; STONER, A.K. Lycopersicon and Solanum spp. resistant to the carmine and the two-spotted spider mite. Journal of Economic Entomology, v.62, p.834-836, 1969.

GONÇALVES, L.D. Herança dos teores de acilaçúcares em genótipos de tomateiro e sua relação com tricomas foliares e repelência ao ácaro Tetranychus evansi. 2006. 60p. Tese (Doutorado) - Universidade Federal de Lavras, Lavras.
GONÇALVES, L.D.; MALUF, W.R.; CARDOSO, M.G.; RESENDE, J.T.V.; CASTRO, E.M.; SANTOS, N.M.; NASCIMENTO, I.R.; FARIA, M.F. Relação entre zingibereno, tricomas foliares e repelência de tomateiros a Tetranychus evansi. Pesquisa Agropecuária Brasileira, v.41, p.267-273, 2006.

GONÇALVES, M.I.F.; MALUF, W.R.; GOMES, L.A.A.; BARBOSA, L.V. Variation of 2-tridecanone level in tomato plant leaflets and resistance to two mite species (Tetranychus sp.). Euphytica, v.104, p.33-38, 1998.

LABORY, C.R.G.; SANTA-CECÍLIA, L.V.C.; MALUF, W.R.; CARDOSO, M.G.; BEARZOTTI, E.; SOUZA, J.C. Seleção indireta para teor de 2-tridecanona em tomateiros segregantes e sua relação com a resistência à traça do tomateiro. Pesquisa Agropecuária Brasileira, v.34, p.733-740, 1999.

LUCKWILL, L.C. The genus Lycopersicon: an historical, biological, and taxonomic survey of the wild and cultivated tomatoes. Aberdeen: Aberdeen University Press, 1943. 44p.

MALUF, W.R.; BARBOSA, L.V.; SANTA-CECÍLIA, L.V.C. 2-tridecanone-mediated mechanisms of resistance to the South American tomato pinworm Scrobipalpuloides absoluta (Meyrick, 1917) (Lepidoptera-Gelechiidae) in Lycopersicon spp. Euphytica, v.93, p.189-194, 1997.

MALUF, W.R.; CAMPOS, G.A.; CARDOSO, M.G. Relationships between trichome types and spider mite (Tetranychus evansi) repellence in tomatoes with respect to foliar zingiberene contents. Euphytica, v.121, p.73-80, 2001.

RESENDE, J.T.V. Resistência a artrópodos-praga mediada por acilaçúcares em tomateiros obtidos do cruzamento interespecífico de Lycopersicon esculentum Mill. 'TOM-584' x L. pennellii 'LA716'. 2003. 91p. Tese (Doutorado) - Universidade Federal de Lavras, Lavras. RESENDE, J.T.V.; MALUF, W.R.; CARDOSO, M.G.; NELSON, D.L.; FARIA, M.V. Inheritance of acylsugar contents in tomatoes derived from an interspecific cross with the wild tomato Lycopersicon pennellii and their effect on spider mite repellence. Genetics and Molecular Research, v.1, p.106-116, 2002.

RESENDE, J.T.V.; MALUF, W.R.; FARIA, M.V.; PFANNI, A.Z.; NASCIMENTO, I.R. Acylsugars in tomato leaflets confer resistance to the South American tomato pinworm, Tuta absoluta Meyr. Scientia Agricola, v.63, p.20-25, 2006.

SAS INSTITUTE. Statistical analysis system: SAS system for linear models. Cary: SAS Institute, 1986. 211p.

SNYDER, J.C.; CARTER, C.D. Leaf trichomes and resistance of Lycopersicon hirsutum and Lycopersicon esculentum to spider mites. Journal of the American Society for Horticultural Science, v.109, p.837-843, 1984.

SNYDER, J.C.; JOHNSON, D.A.; GOOD, D.E.; WESTON, P.A. Type VI trichome exudates from chemotypes of L. hirsutum and L. hirsutum f. glabratum. Report of the Tomato Genetics Cooperative, v.37, p.67-68, 1987

WESTON, P.A.; SNYDER, J.C. Thumbtack bioassay: a quick method for measuring plant resistance to two-spotted spider mites (Acari: Tetranychidae). Journal of Economic Entomology, v.83, p.501-504, 1990. 